\title{
The possible occurrence of cranial asymmetry in three harrier (Accipitridae: Circus) species
}

\author{
Tibor PECSICS ${ }^{1 *}$, András MARX ${ }^{2} \&$ Tibor CsÖRGÖ ${ }^{3}$
}

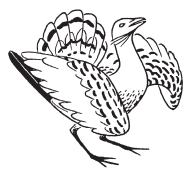

Received: May 21, 2021 - Revised: June 02, 2021 - Accepted: June 03, 2021

Pecsics, T., Marx, A. \& Csörgő, T. 2021. The possible occurrence of cranial asymmetry in three harrier (Accipitridae: Circus) species. - Ornis Hungarica 29(1): 139-148. DOI: 10.2478/ orhu-2021-0011

\begin{abstract}
The harriers (Accipitridae: Circus) represent a unique group of raptorial birds due to their hunting behaviour and their facial ruff and prominent facial disc. During previous studies it was suggested that harrier species may have other convergent features shared with owls like asymmetric or enlarged ear openings related to sensitive hearing capabilities. In this study, cranial asymmetry was done using SAGE (Symmetry and Asymmetry of Geometric Data) software. 32 skulls of 3 species (Western Marsh Harrier (Circus aeruginosus) $\mathrm{n}=8$, Montagu's Harrier (Circus pygargus) $\mathrm{n}=10$, Hen Harrier (Circus cyaneus) $\mathrm{n}=14$ ) were photographed, digitized and assigned with 2D landmarks with TpsDig software. The variables were analysed based on Generalized Procrustes analysis. The morphometric data showed cranial asymmetry of harriers. This asymmetry should rather be explained by foraging strategies as the results are corresponding to the exceptionally good hearing of these species among diurnal raptors.
\end{abstract}

Keywords: cranial morphology, morphometrics, anatomy, skull, shape, convergent evolution, harrier, auditory system

Összefoglalás A rétihéják (Accipitridae: Circus) egyedi képviselői a ragadozó madaraknak, köszönhetően sajátos vadászati technikájuknak és megjelenésüknek, a tollak által alkotott gallérral és arcfátyollal. A korábbi kutatások során felvetődött, hogy utóbbiakon kívül más konvergens tulajdonságokon is osztozhatnak a baglyokkal, mint amilyen az aszimmetrikus vagy megnagyobbodott fülnyílás, amely érzékeny hallásukra utal. Jelen tanulmányban a koponya aszimmetria vizsgálatát a SAGE (Symmetry and Asymmetry of Geometric Data) szoftver segítségével végeztük. Összesen 3 faj 32 koponyájának (barna rétihéja - Circus aeruginosus, $\mathrm{n}=8$, hamvas rétihéja - Circus pygargus, $\mathrm{n}=10$, kékes rétihéja - Circus cyaneus, $\mathrm{n}=14$ ) fényképét digitalizálva, kétdimenziós landmarkokkal láttuk el azokat a TpsDig programban. A változókat Prokrusztész analízis segítségével vizsgáltuk, ahol a morfometriai adatok aszimmetriát mutattak a rétihéja koponyákon. Ez az aszimmetria a táplálkozásmóddal és viselkedéssel köthető össze és megerősíti azt a megállapítást, miszerint nappali ragadozókhoz mérten ezek a madarak kifinomult hallással rendelkeznek.

Kulcsszavak: koponyasajátosságok, morfometria, anatómia, koponya, alak, konvergens evolúció, rétihéja, táplálékpreferencia, auditív érzékelés

${ }^{1}$ Behavioural Ecology Group, Department of Systematic Zoology and Ecology, Eötvös Loránd University, 1117 Budapest, Pázmány Péter sétány 1/C, Hungary

${ }^{2}$ Department of Ethology, Eötvös Loránd University, 1117 Budapest, Pázmány Péter sétány 1/C, Hungary

${ }^{3}$ Department of Anatomy, Cell- and Developmental Biology, Eötvös Loránd University, 1117 Budapest, Pázmány

Péter sétány $1 / C$, Hungary

*corresponding author, e-mail: nobilis.equus@gmail.com 


\section{Introduction}

The harriers (Accipitridae: Circus) represent a unique group of raptorial birds due to their particular hunting behaviour (Redpath 1992), low, quartering flight, exceptionally light wing loading, their mating pattern of polygyny. In their external appearance, harriers are one of the most easily recognisable Accipitrinae raptors due to their external features such as facial ruff and prominent facial disc (Simmons 2000). Harriers have traditionally been placed within the subfamily Circinae (Peters 1931), but recent molecular studies have revealed that harriers are more closely related to Accipiter (Nagy \& Tökölyi 2014, Oatley et al. 2015). The feeding strategies are highly diverse and the morphological adaptations for feeding are a notable feature of avian evolution (Zusi 1993, Zweers et al. 1994). As in many other avian groups, food supply is one of the main factors influencing the ecology of raptors. Population densities of raptors are often limited by food supply (Newton 1980, Franklin et al. 2000), which also influences the number of specialist hunters being more likely to fluctuate annually when dependent on a fluctuating food source (Hamerstrom 1969, Korpimäki \& Norrdahl 1991, Butet \& Leroux 1993).

Previously, the adaptive significance of the anatomical and behavioural convergence between the harriers and some owl species was examined (Clark et al. 2020). Anatomically, both groups evolved a sound collecting facial ruff, a curved structure of skin and feathers surrounding the ears, and forage very close to the ground, harriers are very vocal birds while gliding over the hunting area (Rice 1980). The harriers circle an area several times listening and looking for prey, as they have exceptionally good hearing among diurnal raptors. It suggests that these species have a highly developed auditory system. The ears are covered by the feathers of the facial disc (Rice 1982). Some owl species also have a pronounced facial disc, guiding sounds into the ear openings. In owls, the beak is pointed downward, increasing the surface area over which the soundwaves are collected by the facial disc (Nishikawa 2002). Many owl species are remarkable for the bilateral asymmetry of the ears which attributes support a highly developed sense of directional hearing (Coles \& Guppy 1988, Pecsics et al. 2018). However, the differences are represented by different tissues of the head (feathers, earflaps, ear holes, etc.), ear asymmetry basically caused by cranial structures only, due to the different positions and orientations of the squamoso-occipital wings. Ear morphology is different in structure and geometry between species (Norberg 1978). The symmetrical ears are representing a most basal form and cranial structure (Nishikawa 2002).

Bilateral symmetry is a subject of widespread interest, and structures with such symmetry are particularly considered when these consist of two mirror copies on opposite sides of the body (Klingenberg et al. 2002). Bilateral symmetry analysis focuses on identifying and measuring the location and extent of symmetry departures in structures, like in the context of matching symmetry, where the two mirror images are considered separated parts of the structure (Torcida et al. 2016).

Ear adaptations are a well-known feature of owl evolution. Also there are some documented size and shape asymmetries in birds (Norbeg 1978, Aparicio \& Bonal 2002, Güntürkün et al. 2000, Parés-Casanova \& Salas-Bosch 2020). It was suggested that harrier species may have 
asymmetric or enlarged ear openings for accurately pinpointing sound (Van Grouw 2012), but our knowledge is still limited regarding the degree and the direction of these skeletal asymmetries.

In this preliminary study, we investigated the cranial diversity among three harrier species. Our objective was to increase our knowledge in the relationship between skull shape and the possible asymmetric skeletal features. For this reason, we investigated shape asymmetries related to hearing capabilities.

\section{Materials and Methods}

\section{Specimens}

This study is based on 32 skulls of 3 species: Western Marsh Harrier (Circus aeruginosus) $\mathrm{n}=8$, Montagu's Harrier (Circus pygargus) $\mathrm{n}=10$, Hen Harrier (Circus cyaneus) $\mathrm{n}=14$. All skulls are from adult specimens belonging to the collection of Eötvös Loránd University (Budapest, Hungary), the collection of the Hungarian Natural History Museum (Budapest, Hungary), Mátra Museum (Gyöngyös, Hungary) and the digital archives of Natural Sciences Museum of Barcelona (Barcelona, Spain). No bird has been killed to obtain its skull; all birds died either of natural causes, whether accidental death or whether death in captivity.

\section{Landmarks and procedures}

The variation of cranial morphology was analysed using landmark-based geometric morphometry. In this study, we tried to find landmarks for this analysis to cover the geometric form of the regio oticalis. Ideal landmarks are discrete and noticeable anatomical features that do not alter their topological positions, providing adequate coverage of the morphology (Zelditch et al. 2004). The landmarks were taken from high resolution $(1200 \times 1600$ pixels $)$ photos. We took 3 photographs from each specimen

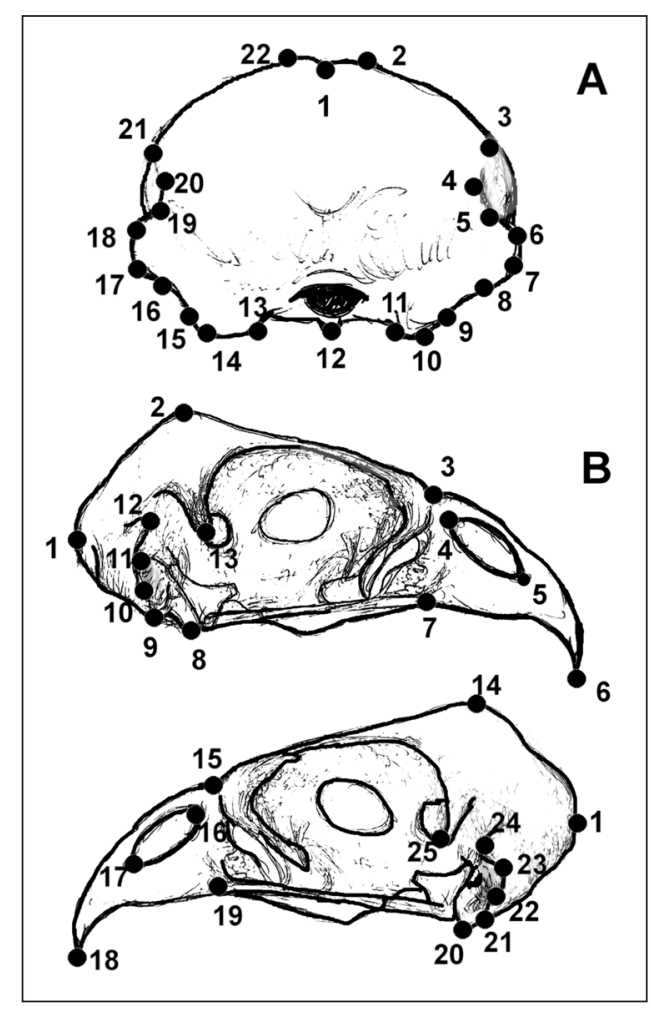

Figure 1. Position and number of landmarks. A: fixed landmarks in caudal view, B: fixed landmarks in lateral (left-right) view (numbers correspond to Table 1)

1.ábra A vizsgálatban használt landmarkok száma és pozíciója. A: fix landmarkok hátulnézetből, B: fix landmarkok oldalnézetből (bal-jobb) (a számok megnevezését lásd a 1. táblázatban) 
(caudal, lateral - right and left). Images were standardised for the foramen magnum occipitale and the tip of the mandible. Testing for fluctuating asymmetry, three measurements were taken (replicates) per individual. For each specimen, 22 fixed landmarks were recorded in caudal view and 25 fixed landmarks in lateral view (right and left) (Figure 1) (Table 1). The coordinates of the landmarks were digitised using TpsDig 2.16 software (Rohlf 2010) and were transformed using the Procrustes superimposition method. We used MannWhitney $\mathrm{U}$ two-tailed test for comparing the sides. To detect the components of variances

Table 1. Number and description of landmarks in caudal (A) and lateral (B) view (terminology according to Baumel 1993, Sun et al. 2018)

1. táblázat Az egyes landmarkok száma és leírása, hátulnézetben (A) és oldalnézetben (B) (terminológia Baumel 1993 és Sun et al. 2018 alapján)

\begin{tabular}{|c|l|}
\hline $\begin{array}{c}\text { A) Number of } \\
\text { landmark }\end{array}$ & \multicolumn{1}{c|}{ Description of landmark } \\
\hline 1 & mid section of the neurocranium \\
\hline 2,22 & highest point of the neurocranium \\
\hline 3,21 & top of curvature at the superior end of the M. add. mandibular externus scar \\
\hline 4,20 & top of curvature at the caudal end of the $M$. add. mandibular externus scar \\
\hline 5,19 & top of curvature at the inferior end of the M. add. mandibular externus scar \\
\hline 6,18 & highest edge of the temporal wing \\
\hline 7,17 & top of curvature at the superior end of the temporal wing \\
\hline 8,16 & top of curvature at the caudal end of the temporal wing \\
\hline 9,15 & top of curvature at inferior end of the temporal wing \\
\hline 10,14 & lowest edge of the temporal wing \\
\hline 11,13 & most inner edge of the temporal wing at the inferior end \\
\hline 12 & lowest point of condylus occipitalis \\
\hline
\end{tabular}

\begin{tabular}{|c|l|}
\hline $\begin{array}{c}\text { B) Number of } \\
\text { landmark }\end{array}$ & \multicolumn{1}{c|}{ Description of landmark } \\
\hline 1 & prominentia cerebellaris \\
\hline 2,14 & highest point of the neurocranium \\
\hline 3,15 & mid-point of the cranio-facial hinge \\
\hline 4,16 & top of curvature at the caudal end of the external nares \\
\hline 5,17 & top of curvature at the rostral end of the external nares \\
\hline 6,18 & tip of the beak \\
\hline 7,19 & articulation point of jugal bar and maxilla \\
\hline 8,20 & the processus of the opisthotic \\
\hline 9,21 & lowest edge of the temporal wing \\
\hline 10,22 & top of curvature at the inferior end of the temporal wing \\
\hline 11,23 & top of curvature at the superior end of the temporal wing \\
\hline 12,24 & highest edge of the temporal wing \\
\hline 13,25 & processus postorbitalis \\
\hline
\end{tabular}


and deviations, Procrustes ANOVA was used (Klingenberg et al. 1998, Marquez 2006). Consensus configurations and relative warps were conducted. Variability in shape was assessed using the scores obtained for each individual on the first two relative warps. Cranial asymmetry was estimated using SAGE (Symmetry and Asymmetry of Geometric Data) software (Marquez 2006). We conducted principal component analyses (PCA) on these morphological variables in caudal view. The relative warps are corresponding to the principal components (PCs) and define the shape space in which individuals are replaced. We used PAST v.1.7 software (Hammer et al. 2001) for principal component analysis and to extract deformation grids. We only considered those PCs which are explaining $>10 \%$ of the variance.

\section{Results}

Mann-Whitney $\mathrm{U}$ two-tailed test showed significant differences between the two sides of the skull regarding the temporal region ( $\mathrm{U}=838.5 ; \mathrm{z}=-8.22, \mathrm{P}<0.001$ at the significance level 0.01 ).

Procrustes ANOVAs revealed that directional asymmetry was greater than fluctuating asymmetry (Table 2) reflecting the coordinates in caudal and lateral view.

During the second analysis, we used 22 fixed landmarks recorded in caudal view. The first two PCs explained $38 \%$, and $22 \%$ of the variance in shape. The first PC described the variation in shape, the second the relative orientation of the temporal wing which showed that Circus species differ considerably in their degree of asymmetry (Figure 2). The Western Marsh Harrier showed less cranial asymmetry than the other two species, Montagu's Harrier was in intermediate position in the analysis and Hen Harrier showed the most asymmetric scores (Figure 3).

Table 2. Results of ANOVA for the registered coordinates in caudal (above) and lateral view (bottom), with the effect of "side" (directional asymmetry) and "side*individual" effect (fluctuating asymmetry)

2. táblázat Az ANOVA eredményei a regisztrált koordináták tekintetében hátulnézetben (fent) és oldalnézetben (alul), az "oldal" (direkcionális aszimmetria) és az "oldal*egyed" (fluktuáló aszimmetria) hatásával

\begin{tabular}{|l|c|c|c|c|c|}
\hline \multicolumn{1}{|c|}{ effect / hatás } & SS & MS & df & F & p \\
\hline individual / egyed & 0.0566 & 0.0004 & 160 & 4.6948 & 0.001 \\
\hline side / oldal & 0.0045 & 0.0002 & 20 & 2.9694 & 0.001 \\
\hline side*individual / oldal*egyed $^{*}$ & 0.0121 & 0.0001 & 160 & 16.7492 & 0.001 \\
\hline error / hiba & 0.0032 & 0.0002 & 720 & & \\
\hline
\end{tabular}

\begin{tabular}{|l|c|c|r|r|r|}
\hline \multicolumn{1}{|c|}{ effect / hatás } & SS & MS & df & \multicolumn{1}{c|}{ F } & \multicolumn{1}{c|}{ p } \\
\hline individual / egyed & 0.0646 & 0.0004 & 184 & 4.7844 & 0.0001 \\
\hline side / oldal & 0.0073 & 0.0003 & 23 & 4.346 & 0.0001 \\
\hline${\text { side*individual / oldal }{ }^{*} \text { egyed }}^{*}$ & 0.0135 & 0.0001 & 184 & 93.4848 & 0.001 \\
\hline error / hiba & 0.0006 & 0.0001 & 828 & & \\
\hline
\end{tabular}




\section{A}

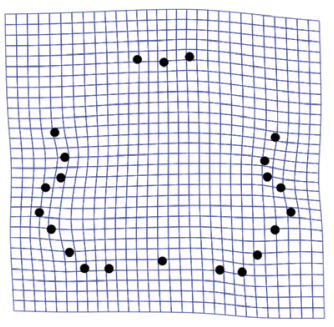

B

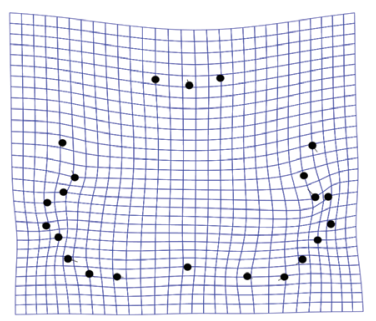

C

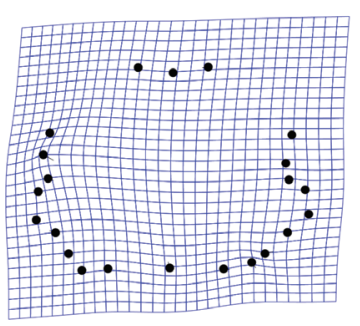

Figure 2. Various harrier species differ considerably in their degree of asymmetry (in caudal view). A: Western Marsh Harrier (Circus aeruginosus), B: Montagu's Harrier (Circus pygargus), C: Hen Harrier (Circus cyaneus)

2. ábra Az egyes rétihéja fajok különböznek az aszimmetria mértékében (hátulnézetben. A: barna rétihéja (Circus aeruginosus), B: hamvas rétihéja (Circus pygargus), C: kékes rétihéja (Circus cyaneus)

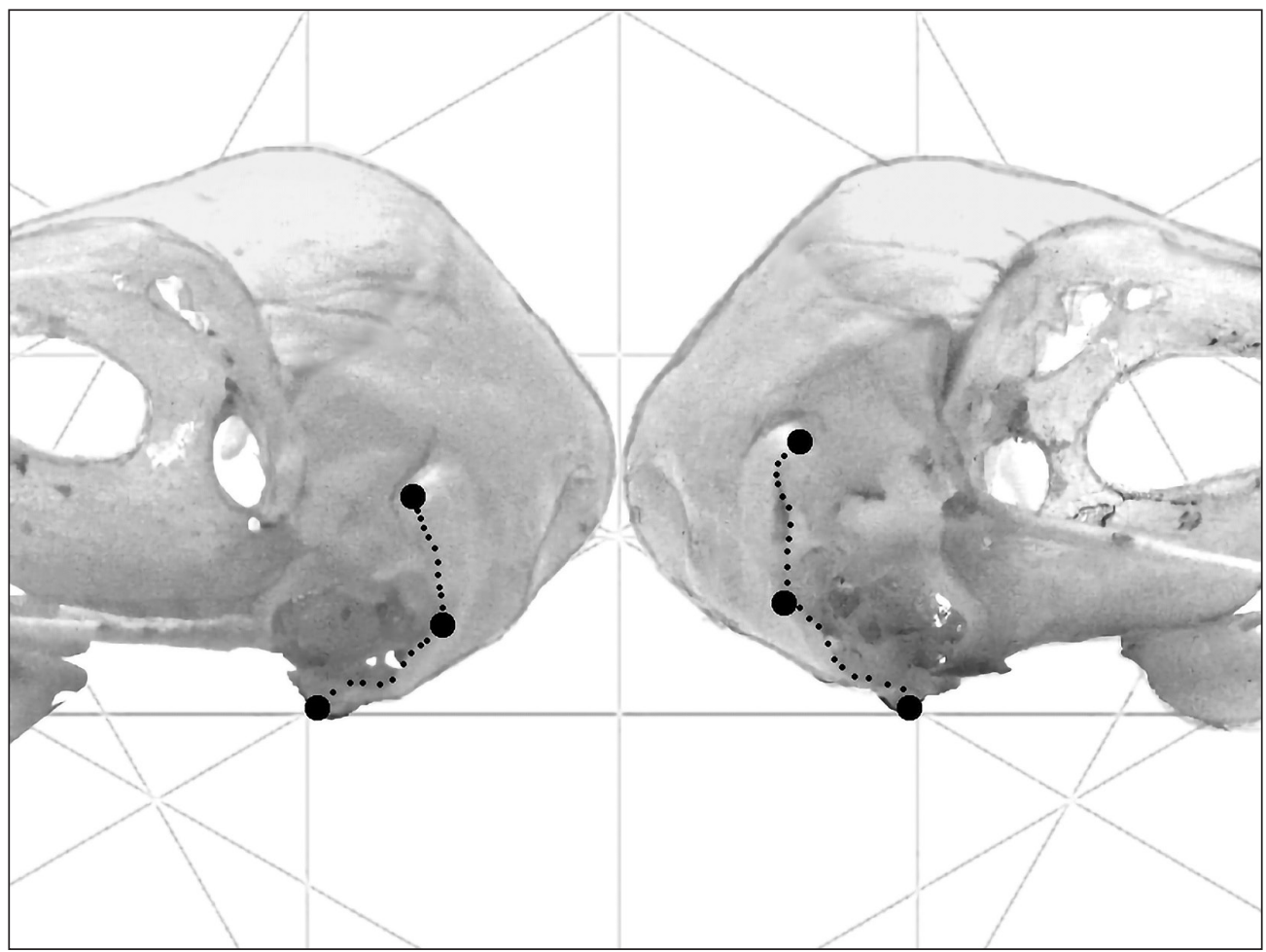

Figure 3. Differences in position and shape of left and right tympanic wings on the skull of a Hen Harrier (Circus cyaneus) specimen

3. ábra A kékes rétihéja (Circus cyaneus) egy példányának koponyáján lévő különbségek a bal és jobb oldali halántékcsont tympanicus nyúlványainak helyzetében és alakjában 


\section{Discussion}

We found that the influence of directional asymmetry was greater than fluctuating asymmetry which suggests that these asymmetrical features probably evolved to support directional hearing and sound localization. In lateral and caudal view, there are differences in the size and orientation of the temporal wing between the species. However, the anatomical similarities between harriers can be explained by their slightly different foraging methods and hunting behaviour.

Comparisons between sympatric raptor species with similar ecological needs and preferences but different body size and social behaviour are helpful in assessing the influence of energy needs or dominance on foraging strategies and food partitioning (Fedriani et al. 2000, Buij et al. 2011). The Montagu's Harrier and the Hen Harrier are breeding and foraging sympatrically in many areas. The diet of these species is very similar (Millon et al. 2002). The species differ in size, Hen Harrier being larger and also there are differences in their breeding system (Cramp 1980). Food partitioning by size between species that differ in food requirements is expected and has been observed in other species too (Gerstell \& Bednarz 1999). Accordingly, within the large spectrum of prey types indicated that Hen Harriers preyed more frequently on larger prey and Montagu's Harriers on smaller prey (including more insects). This kind of segregation was observed in the main prey (small lagomorphs and rodents), and in the sizes of the most important alternative prey (Garcia \& Arroyo 2002, Arroyo \& Garcia 2006, Arroyo 2008).

The competition between Western Marsh and Hen Harriers for hunting space in the same area was also observed, i.e. Western Marsh Harriers hunted mainly over the marsh (Buij 2012, Tornberg \& Haapala 2013) resulting in niche separation between the two species. Western Marsh Harrier has proportionately shorter wings and tail, its flight is slower and less manoeuvrable compared to Hen Harrier. Western Marsh Harrier has longer tarsi which should be an adaptation to reach deep into tall marsh vegetation preferred to hunt, maybe because this gave it more opportunity for surprise during hunting (Clarke et al. 1993, Cardador et al. 2012).

Differences in foraging efficiency between generalist and specialist species could be explained by neural limitations. This means that generalists need learning to be able to narrow their resource choices (Bernays et al. 2004). Specialization may be also associated with morphological or behavioural adaptations to handle certain resources. Harriers are diurnal raptors but evolved a parabolic collar of feathers surrounding the eyes, suggesting that hearing is enhanced to locate small mammal prey hiding in dense vegetation (Rice 1982, Redpath 1992, Simmons 2000). The facial disc is more pronounced in those harrier species which are feeding on mainly small rodent prey like the Pallid Harrier (Circus macrourus) (Buij 2012). The facial disc encircling the ears and meeting below the beak, in contrast, the facial disc of the Montagu's Harrier is confined to an arc just behind the ear openings, suggesting its hearing capacities might be less well developed than that of the rodent specialist species (Clarke et al. 2008, Terraube et al. 2011). This is also in accordance with our results. The Western Marsh Harrier is a great opportunist with lack of specialization (which means very wide range of prey, varying with local availability) 
showed less asymmetrical features. The Montagu's Harrier is feeding on small ground birds, small mammals, reptiles and large insects (Thiollay 1994) but the Hen Harrier (which preys on mostly small rodents, like voles, mice, cotton rats, ground squirrels) (Garcia \& Arroyo 2004) showed greater asymmetries in temporal region than the other two species. It suggests that feeding mainly on small rodents requires more sensitive auditory capabilities to detect the movement of the prey item. It is also possible that the relative size of the facial disc is in relationship with asymmetrical cranial structures, which also connected with hearing and auditory capabilities in owls (Norberg 2002). In the case of Hen Harrier some kind of nocturnal behaviour (Russell 1991) may have also effect on this feature.

Our results show relationships between cranial asymmetry and hunting behaviour but also highlight the morphological complexity and diversity of raptor skulls. Future studies should rather examine the possible interspecific and intersexual differences that may have effect on the cranial morphology and asymmetry of these birds. With a larger sample size (including more harrier species) and using parameters of soft tissues of the ear and temporal region will create a more complex vision regarding the evolution of asymmetrical features which are supporting directional hearing. New investigations reflecting on cranial asymmetries may increase our knowledge to understand how these special features are functioning in living specimens.

\section{Acknowledgements}

We are grateful to Gergely Babocsay, Miklós Laczi, Tamás Kondor, Martin Segesdi and Péter Urtz for the technical assistance. The text was supervised by Bridgette Dennett, Emese Bodor and Jenő Nagy.

\section{References}

Aparicio, J. M. \& Bonal, R. 2002. Why do some traits show higher fluctuating asymmetry than others? A test of hypotheses with tail feathers of birds. - Heredity 89(2): 139-144.

Arroyo, B. E. 2008. Diet of Montagu's Harrier Circus pygargus in central Spain: analysis of temporal and geographic variation. - Ibis 139(4): 664-672. DOI: 10.1111/j.1474-919x.1997.tb04689.x

Arroyo, B. E. \& Garcia, J. T. 2006. Diet composition influences annual breeding success of Montagu's Harriers Circus pygargus feeding on diverse prey. - Bird Study 53(1): 73-78. DOI: 10.1080/00063650609461418

Baumel, J. J. 1993. Handbook of avian anatomy: Nomina Anatomica Avium. - Publications of the Nuttall Ornithological Club (USA), no. 23

Bernays, E. A., Singer, M. S. \& Rodrigues, D. 2004. Foraging in nature: foraging efficiency and attentiveness in caterpillars with different diet breadths. - Ecological Entomology 29(4): 389-397. DOI: 10.1111/j.03076946.2004.00615.x

Buij, R. 2012. Pallid Harrier Circus macrourus bird hunting behaviour and capture success in northern Cameroon. - Ostrich 83(1): 27-32. DOI: 10.2989/00306525.2012.680263

Buij, R., Van der Goes, D., De Iongh, H. H., Gagare, S., Haccou, P., Komdeur, J. \& De Snoo, G. 2011. Interspecific and intraspecific differences in habitat use and their conservation implications for Palaearctic harriers on Sahelian wintering grounds. - Ibis 154(1): 96-110. DOI: 10.1111/j.1474-919x.2011.01200.x

Butet, A. \& Leroux, A. A. 1993. Effect of prey on a predator's breeding success. A 7 year study on common vole (Microtus arvalis) and Montagu's Harrier (Circus pygargus) in a west France marsh. - Acta Oecologica (Montrouge) 14(6): 857-865. 
Cardador, L., Planas, E., Varea, A. \& Mañosa, S. 2012. Feeding behaviour and diet composition of Marsh Harriers Circus aeruginosus in agricultural landscapes. - Bird Study 59(2): 228-235. DOI: 10.1080/00063657.2011.648165

Clark, C. J., LePiane, K. \& Liu, L. 2020. Evolutionary and ecological correlates of quiet flight in nightbirds, hawks, falcons, and owls. - Integrative and Comparative Biology 60(5): 1123-1134. DOI: 10.1093/icb/icaa039

Clarke, R., Bourgonje, A. \& Castelijns, H. 1993. Food niches of sympatric Marsh Harriers Circus aeruginosus and Hen Harriers C. cyaneus on the Dutch coast in winter. - Ibis 135(4): 424-431. DOI: 10.1111/j.1474919x.1993.tb02115.x

Clarke, R., Combridge, M. \& Combridge, P. 2008. A comparison of the feeding ecology of wintering Hen Harriers Circus cyaneus centred on two heathland areas in England. - Ibis 139(1): 4-18. DOI: 10.1111/j.1474919x.1997.tb04498.x

Coles, R. B. \& Guppy, A. 1988. Directional hearing in the Barn Owl (Tyto alba). - Journal of Comparative Physiology A, 163(1): 117-133. DOI: 10.1007/bf00612002

Cramp, S. 1980. Handbook of the birds of Europe, the Middle East, and North Africa: the birds of the western Palearctic, Vol. 2. Hawks to bustards. - Oxford University Press

Fedriani, J. M., Fuller, T. K., Sauvajot, R. M. \& York, E. C. 2000. Competition and intraguild predation among three sympatric carnivores. - Oecologia 125: 258-270. DOI: 10.1007/s004420000448

Franklin, A. B., Anderson, D. R., Gutiérrez, R. J. \& Burnham, K. P. 2000. Climate, habitat quality, and fitness in Northern Spotted Owl populations in northwestern California. - Ecological Monographs 70(4): 539-590. DOI: 10.1890/0012-9615(2000)070[0539:chqafi]2.0.co;2

Garcia, J. T. \& Arroyo, B. E. 2002. Intra- and interspecific agonistic behaviour in sympatric harriers during the breeding season. - Animal Behaviour 64(1): 77-84. DOI: 10.1006/anbe.2002.3035

Garcia, J. T. \& Arroyo, B. E. 2004. Food-niche differentiation in sympatric Hen Circus cyaneus and Montagu's Harriers Circus pygargus. - Ibis 147(1): 144-154. DOI: 10.1111/j.1474-919x.2004.00377.x

Gerstell, A. T. \& Bednarz, J. C. 1999. Competition and patterns of resource use by two sympatric raptors. Condor 101: 557-565.

Güntürkün, O., Diekamp, B., Manns, M., Nottelmann, F., Prior, H., Swartz, A. \& Skiba, M. 2000. Asymmetry pays: Visual lateralization improves discrimination success in Pigeons. - Current Biology 10(17): 1079-81. DOI: $10.1016 / \mathrm{s} 0960-9822(00) 00671-0$

Hamerstrom, F. 1969. A harrier population study. - In: Hickey, J. J. (ed.) Peregrine Falcon Populations: Their Biology and Decline. - Wisconsin University Press, Wisconsin, pp. 367-383.

Klingenberg, C. P., Barluenga, M. \& Meyer, A. 2002. Shape analysis of symmetric structures: quantifying variation among individuals and asymmetry. - Evolution 56(10): 1909-1920. DOI: 10.1111/j.00143820.2002.tb00117.x

Korpimäki, E. \& Norrdahl, K. 1991. Do breeding nomadic avian predators dampen population fluctuations of small mammals? - Oikos 62(2): 195-208. DOI: 10.2307/3545265

Marquez, E. 2006. Sage: symmetry and asymmetry in geometric data. - Ver 1.0.http://www.personal.umich. edu/ emarquez/morph/

Millon, A., Bourrioux, J. L., Riols, C. \& Bretagnolle, V. 2002. Comparative breeding biology of Hen and Montagu's Harriers: an eight-year study in north-eastern France. - Ibis 144: 94-105. DOI: 10.1046/j.00191019.2001.00009.x

Nagy, J. \& Tökölyi, J. 2014. Phylogeny, historical biogeography and the evolution of migration in accipitrid birds of prey (Aves: Accipitriformes). - Ornis Hungarica 22: 15-35. DOI: 10.2478/orhu-2014-0008

Nishikawa, K. C. 2002. Evolutionary convergence in nervous systems: insights from comparative phylogenetic studies. - Brain, Behavior and Evolution 59(5-6): 240-249. DOI: 10.1159/000063561

Newton, I. 1980. The role of food in limiting bird numbers. - Ardea 55(1-2): 11-30.

Norberg, R. Å. 1978. Skull asymmetry, ear structure and function, and auditory localization in Tengmalm's Owl, Aegolius funereus (Linné). - Philosophical Transactions of the Royal Society of London, Biological Sciences 282(991): 325-410. DOI: 10.1098/rstb.1978.0014

Norberg, R. Å. 2002. Independent evolution of outer ear assymmetry among five owl lineages; morphology, function and selection. - In: Newton, I., Kavanagh, R., Olsen, J. \& Taylor, I. (eds.) Ecology and Conservation of Owls. - Collingwood, Victoria, Australia: Csiro Publishing, pp. 329-42.

Oatley, G., Simmons, R. E. \& Fuchs, J. 2015. A molecular phylogeny of the harriers (Circus, Accipitridae) indicate the role of long distance dispersal and migration in diversification. - Molecular Phylogenetics and Evolution 85: 150-160. DOI: 10.1016/j.ympev.2015.01.013 
Parés-Casanova, P. M. \& Salas-Bosch, J. 2020. Comparison of orbital asymmetries among some raptor species: "when size does not matter". - Slovak Raptor Journal 14(1): 23-27. DOI: 10.2478/srj-2020-0005

Pecsics, T., Laczi, M., Nagy, G., Kondor, T. \& Csörgö, T. 2018. Analysis of skull morphometric characters in Owls (Strigiformes). - Ornis Hungarica 26(1): 41-53. DOI: 10.1515/orhu-2018-0003

Peters, J. L. 1931. Check-list of Birds of the World. - Harvard University Press, Cambridge

Redpath, S. M. 1992. Behavioural interactions between Hen Harriers and their moorland prey. - Ornis Scandinavica 23(1): 73-80. DOI:10.2307/3676429

Rice, W. R. 1980. Acoustical localization of concealed prey by the diurnal harrier (Circus cyaneus). - PhD Dissertation, Corvallis, Oregon, Oregon State University

Rice, W. R. 1982. Acoustical location of marsh hawk: adaptations to concealed prey. - Auk 99: 403-413.

Rohlf, F. J. 2010. TpsDig, version 2.16. - Department of Ecology and Evolution, State University of New York, Stony Brook, USA

Russell, R. W. 1991. Nocturnal flight by migrant "diurnal” raptors. - Journal of Field Ornithology 62(4): 505-508.

Simmons, R. E. 2000. Harriers of the World: Their Behaviour and Ecology, Oxford Ornithology Series, 11. Oxford University Press on Demand

Sun, Y., Si, G., Wang, X., Wang, K. \& Zhang, Z. 2018. Geometric morphometric analysis of skull shape in the Accipitridae. - Zoomorphology 137: 445-456. DOI: 10.1007/s00435-018-0406-y

Terraube, J., Arroyo, B., Madders, M. \& Mougeot, F. 2011. Diet specialisation and foraging efficiency under fluctuating vole abundance: a comparison between generalist and specialist avian predators. - Oikos 120(2): 234-244. DOI: 10.1111/j.1600-0706.2010.18554.x

Thiollay, J. M. 1994. Accipitridae (Hawks and eagles). - In: del Hoyo, J., Elliott, A., Sargatal, J., Christie, D. A. \& de Juana, E. (eds.) 1992-2011. Handbook of the Birds of the World, Vol. 2. New World Vultures to Guineafowl. - Lynx Edicions, Barcelona, pp. 52-206.

Torcida, S., Gonzalez, P. \& Lotto, F. 2016. A resistant method for landmark-based analysis of individual asymmetry in two dimensions. - Quantitative Biology 4(4): 270-282. DOI: 10.1007/s40484-016-0086-X

Tornberg, R. \& Haapala, S. 2013. The diet of the Marsh Harrier Circus aeruginosus breeding on the isle of Hailuoto compared to other raptors in northern Finland. - Ornis Fennica 90(2): 103-116.

Van Grouw, K. 2012. I. Accipitres. - In: The Unfeathered Bird. - Princeton University Press, pp. 30-51. DOI: $10.1515 / 9781400844890.30$

Zelditch, M., Swiderski, D., Sheets, D. H. \& Fink, W. 2004. Geometric Morphometrics for Biologists: A primer. - Elsevier Academic Press, Waltham, MA.

Zusi, R. L. 1993. Patterns of diversity in the avian skull. - In: Hanken, J. \& Hall, B. K. (eds.) The Skull, Vol. 2. Patterns of Structural and Systematic Diversity. - University of Chicago Press, Chicago, pp. 391-437.

Zweers, G. A., Berkhoudt, H. \& Berge, J. V. 1994. Behavioral mechanisms of avian feeding. - In: Bels, V. L., Chardon, M. \& Vandewalle, P. (eds.) Biomechanics of Feeding in Vertebrates. - Springer, Berlin, Heidelberg, pp. 241-279.

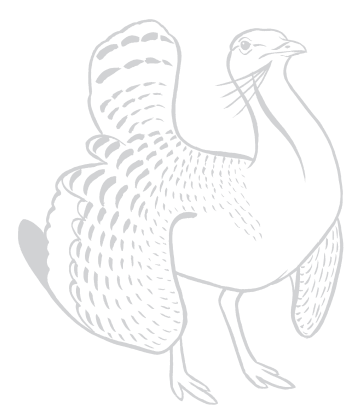

